\title{
A Portfolio Model for the Teaching and Learning of GIS Competencies in An Upper Secondary School: A Case Study from A Finnish Geomedia Course
}

\author{
Henna ANUNTI 1 \\ University of Oulu, Oulu \\ FINLAND
}

\author{
EsSi VUOPALA ${ }^{2}$ \\ University of Oulu, Oulu \\ FINLAND
}

\author{
Jarmo RUSANEN 3 \\ University of Oulu, Oulu \\ FINLAND
}

\begin{abstract}
${ }^{1}$ Corresponding author: MSc, PhD Candidate, Geography Research Unit, PL 8000 FI-90014 University of Oulu, Finland. henna.anunti [at]ii.fi, ORCID: 0000-0002-3296-0941

${ }^{2}$ University Lecturer, Department of Educational Sciences and Teacher Education, Learning and Educational Technology Research Unit (LET), e-mail: essi.vuopala[at]oulu.fi, ORCID: 0000-0001-6158-9080

${ }^{3}$ Professor of Geoinformatics (emeritus), Geography Research Unit, University of Oulu, e-mail: jarmo.rusanen[at]oulu.fi, ORCID: 0000-0001-9661-3765
\end{abstract}

\begin{abstract}
The fast rate of technological development in today's modern, digitalized society provides new opportunities and challenges for the future of geography education. The availability of geographic applications and geographical information systems (GIS) also create many interesting possibilities for the analysis, interpretation and production of geographic information (GI). The objective of this paper is to explore and discuss how a digital GIS portfolio can be used as an educational method for teaching and learning about the use of GIS. In this study, a design-based research (DBR) approach is used to develop a portfolio model for use in a Geomedia course in an upper secondary school setting. The design process occurred during January 2019 with pre-service teachers $(n=8)$ and Geography teachers $(n=2)$ at a university in Finland. There were six development cycles including problem analysis, design process and design solutions. The idea of a DBR approach is not only to create instructional materials to support students' in their learning and development of GIS skills, but also to be an educative process for pre-service teachers who have minimal experience in teaching GIS skills. The digital GIS portfolio model follows Bloom's taxonomy and includes progressively more demanding, inquiry-based activities for students. The digital GIS portfolio as a pedagogical practice was tested during Spring semester in 2019 with students $(\mathrm{n}=17)$ who were completing a Geomedia course at a local upper secondary school. It turned out that the use of a digital GIS portfolio is a very promising method for GIS education. Use of the portfolio improved student competence at using GIS; it developed student motivation to learn about GIS; and increased students' perceptions about the importance of GIS. However, a teacher-centered approach for teaching about GIS skills was also considered to be very important. The results of this study provide practical knowledge for Geography teachers and useful advice for developing teacher training in Geography.
\end{abstract}

\section{Keywords}

GIS Education, Upper Secondary School, Geomedia, Educational Portfolio

To cite this article: Anunti, H.; Vuopala, E., Rusanen, J. (2020). A Portfolio Model for the Teaching and Learning of GIS Competencies in an Upper Secondary School: A Case Study from a Finnish Geomedia Course. Review of International Geographical Education (RIGEO), 10(3), 262-282. Retrieved from http://www.rigeo.org/vol10no3/Number3Summer/RIGEOV10-N3-1.pdf. doi: 10.33403rigeo.741299 
The acquisition of spatial competence is considered to be one of the major tasks in the study of Geography, especially in the secondary school years (Barnikel \& Ploetz, 2015). Earlier studies (e.g. Baker, Kerski, Huynh, Viehrig \& Bednarz, 2012; Kerski, Demirci, \& Milson, 2013; Bearman, Jones, André, Cachinho \& DeMers, 2016; Anunti, Vuopala \& Rusanen, 2018) show that technological development creates great opportunities for using GIS in secondary education to help students develop their geographical competence. West (2007), Favier \& Schee (2014) and Bearman et al., (2016) each discuss the role of GIS education in promoting students' critical spatial thinking skills and multiliteracy skills in the context of GIS-supported inquiry-based learning. The use of GIS provides an ideal instrument for studying geographical problems and phenomena. When GIS is applied to the processes of posing and answering geographic questions, acquiring geographic resources and visualizing geographic data, it is evident that the use of GIS also engages students and facilitates the development of higher-order thinking skills. Critical-thinking skills and multi-literacy skills are considered to be important transversal competencies, so integrating GIS into the teaching of Geography will promote the development and acquisition of such $21^{\text {st }}$ century skills (Finnish National Agency of Education 2016).

However, despite the advances in educational technology and the availability of GIS resources, the use of GIS in teaching is challenging and broadly its use has not yet broken through in secondary education (Favier \& Schee, 2014; Esteves \& Rocha, 2015). Therefore, the implication is for a need to develop educational GIS practices and materials that combine curricula with standards of competency (Schubert \& Uphues, 2009; Hirvensalo \& Koskelo, 2014). Also, the development of new technological tools and increasing access to GIS resources requires more flexible and alternative approaches towards the teaching and learning about the use of GIS overall, particularly in secondary education. Such approaches should be explored because the spread of GIS in education has proceeded slowly (Baker \& Bednarz, 2012; Tate \& Jarvis, 2017).

In summary, although the importance of GIS in education is acknowledged there is a need for additional research to occur which focuses on the support systems required for teacher training about the use of GIS. Therefore, the aim of this study is to design a digital GIS portfolio, which aligns with the Geography curriculum and implements GIS education material in a research context. Therefore, a case study example is used to demonstrate a design process where a collaborative design approach is applied with pre-service teachers. The key purpose of this paper is to discuss the possibilities and challenges about the use of a digital GIS portfolio as a pedagogical method for GIS education at the upper secondary level. Thus, the following research questions are set:

Research Question 1. Which factors affect the teaching of GIS competencies?

Research Question 2. How does the use of digital GIS portfolios contribute to the development of GIS competencies in students? 


\section{Theoretical Framework}

\section{Geographical Skills and GIS Competencies}

Since the 1990s, research about the use of GIS in education has slowly emerged as its own field, focusing on how and what can be taught and learnt by teachers and students when using spatial data and GIS tools. Furthermore, researchers have explored how content standards, national curricula and societal trends influence the development of and importance placed on spatial thinking skills and the use of GIS (Baker et al., 2012; Baker et al. 2015).

Zwartjes \& Torres (2019) and Donert et al. (2016) each present a list of spatial thinking competencies and geospatial thinking learning lines for secondary education as developed from the Geographical Information (GI) Learner project. The GI Learner competencies include the critical use of cartographic material, the use of GI applications and GI interfaces, GI data collection techniques, and the evaluation of GI data (Donert et al., 2016, p. 141-142, GI Learner Competencies, 2017).

As Havelková \& Hanus (2019) suggest, authors differ in their definitions of geographical skills including geospatial thinking skills and mapping skills. In this study, geographical skills are defined in reference to the definition from the Finnish curriculum about geomedia and geographical research skills: "the knowledge of the basics of cartography and the use of geographical information system as well as setting problems and acquiring, processing, analyzing, interpreting, evaluating and presenting geographical research data" (Finnish National Board of Education 2015, p. 160). As motivation is an important factor to consider in promoting learning about how to use GIS (West, 2007), the current study also took into account the students' motivations and attitudes towards learning about how to use GIS when defining GIS competencies.

\section{GIS in Finnish Secondary Education}

The role of GIS in the Finnish national curriculum for Geography shows great heterogeneity with other countries (Kerski et al., 2013). According to the Finnish National Core Curriculum for General Upper Secondary Schools (Finnish National Board of Education 2015), the aim of teaching and learning in Geography is to help students develop a geographic worldview so as to understand a range of global, regional and local phenomena, challenges and potential solutions. The inquirybased approach and versatile use of geomedia (e.g. maps, GIS, diagrams, images, videos, literacy sources, oral presentations and other media) will support the student to acquire, analyze, and interpret and visually present geographic data. The curriculum-based goals also include the student being able to understand, interpret, apply and evaluate different forms of geomedia including GIS. Geography education in Finland familiarizes students with spatial planning methods as well as how to observe and assess the state of the environment. Furthermore, the learning of Geography should develop student interest in geographic information. Assessment in Geography focuses on the student's knowledge and expertise about basic concepts as well as the student's ability to understand, apply, analyze, present and 
assess geographical information in different situations (Finnish National Board of Education, 2015).

In Finland's national core curriculum for Geography in the upper secondary years, there is one compulsory course (GE1 the World of Change) for all students to complete, and there are three national specialization courses (GE2 the Blue Planet, GE3 a Common World and GE4 Geomedia - Explore, Participate, and Get involved). All of the course-specific objectives and content include geographic research skills and use of geomedia (Finnish National Board of Education, 2015). GIS is not specifically mentioned in the course descriptions for GE1, GE2 and GE3. However, GIS is included in the versatile use of geomedia and geographic sources. As an overall summary concerning GIS education, it can be concluded that the curriculum for secondary Geography education emphasizes teaching with GIS in order to develop students' GIS skills in practice, rather than teaching them about GIS by focusing on its technological foundations.

In the GE4 Geomedia course students apply their geographic knowledge and skills acquired from previous courses to conduct either a small-scale geographic study or a participation and/or involvement project with a local, regional or global dimension. The aim of the course is for each student to be able to pose geographic questions and use geomedia in an appropriate way to search and present geographic data. Core content of the Geomedia course include the basics of cartography and GIS together with the use of GIS applications (Finnish National Board of Education, 2015; National Board of Education, 2019).

In Finland, the national curriculum has recently been revised and a new national curriculum will commence in Autumn 2021. There will be no significant changes to the contents and objectives of the Geography curriculum or to GIS education (National Board of Education, 2019).

A limited amount of research focused on GIS education exists in Finland. Hirvensalo \& Koskelo (2014) conclude there is a need to create innovative practices to integrate information and communication technology (ICT) with the teaching of Geography. The use of GIS provides an excellent tool to explore societal and environmental issues.

\section{Educational Portfolio in Teaching and Learning of Geography}

Portfolios are purposeful collections to exhibit the efforts, progress, and achievements of student learning. Portfolios demonstrate student ability and their results of learning which are derived from the educational goals of the portfolio and aims of the curriculum (Martin-Kniep, 1998). Furthermore, portfolios can be designed and used for alternative and continuous assessment tasks as well as for supporting the more traditional summative assessment tasks such as tests and exams; also, portfolios provide a tool to monitor, collect and document student progress in the development of their Geography skills (Ugodulunwa \& Wakjissa, 2015). 
In Geography education, individual starting points for active knowledge construction can be taken from a student's existing-knowledge and understanding about spatial concepts. Students often have very different levels of competency in geographical skills, especially in the utilization of GIS, open data and GIS applications (Barnikel \& Bloetz, 2015). As in all process of learning, including instruction in Geography, the complexity of topics, tasks and applied methods may be gradually increased in accordance with students' abilities (Chatel \& Falk, 2017). Depending on the teaching and learning objectives in response to the needs and abilities of the target group, a digital portfolio for teaching and learning about the use of GIS skills provides a versatile learning arrangement for the classroom and for fieldwork. Instead of teacher-centered and textbook-based approaches, the wide access available to digital maps and retrieval of open GIS data offer diverse opportunities to design student-centered assignments that require acquisition and analysis of geographic information in a variety of ways. The options cover a wide range of existing online resources to enable the development of basic learning tasks (such as browsing through different map levels or finding and marking a location on a map) and also provide the opportunity to create more demanding explorative tasks. For example, an inquiry-based task will allow students to collect geographical data in the field by using GIS applications, and also to develop observation skills and promote their learning about the use of GIS (Lee, 2020). Student-centered knowledge production dramatically increases learners' awareness about and understanding of the phenomena being studied (Chatel \& Falk, 2017). Thus, by using GIS programs and applications students will reach a deeper understanding about how to illustrate space and content in an interesting and relevant way (Barnikel \& Ploetz, 2015).

To sum up, the use of a digital GIS portfolio, which includes alternative assignments at different levels of difficulty, will allow students to choose tasks in correspondence with their level of competence; additionally, they can progress at their own pace from the easiest to the most difficult tasks. Such a pedagogical approach provides students with an opportunity to work relatively autonomously towards the learning goals. Previous studies indicate the use of portfolios do promote student engagement in learning (Simon \& Renee Forgette-Giroux, 2000). Furthermore, use of a portfolio assists with making learning more relevant to the students as they can collect and retain a record of their efforts and progress in learning (Ugodulunwa \& Wakjissa, 2015). As a result, Ugodulunwa \& Wakjissa (2015) suggest teachers adopt the use of portfolios to make student learning more meaningful and applicable to a real-life context.

\section{Methodology}

\section{Research Design}

This study followed a design-based research (DBR) approach. DBR has been applied successfully in many studies related to the development of teaching materials and educational innovations (e.g. Edelson, 2002; Pernaa \& Aksela, 2012; Oikarinen, 2016; Vartiainen, 2016; Tuomisto, 2018). DBR is also a recommended 
method for developing instructional materials in Geography (Schell et al., 2013) and also for conducting an inquiry-based, GIS-supported project (Favier \& Joop, 2014). In the current study, by implementing a design process through a DBR approach, the ultimate aim is to produce instructional materials through a carefully designed and properly executed process according to the recommendations for $21^{\text {st }}$ Century education in Geography. Instructional materials should be built upon students' prior knowledge and skills. However, activities should also challenge students' geographical thinking and use a variety of geographical practices and tools (Schell, et al., 2013). As most instructional materials focus on supporting student learning, in this study, the other main objective is to design instructional materials through a process that will support the development of pre-service teachers' competencies in GIS education. By developing instructional materials through DBR, an authentic educative setting occurs for pre-service teachers and provides an opportunity for collaboration to occur between pre-service and in-service teachers. The role of preservice and in-service teachers were to actively contribute to design the structure and content of digital GIS portfolio (See Figure 1).

\section{Design Challenge: An Educational Portfolio for Teaching and Learning About the Use Of GIS}

Phase 1

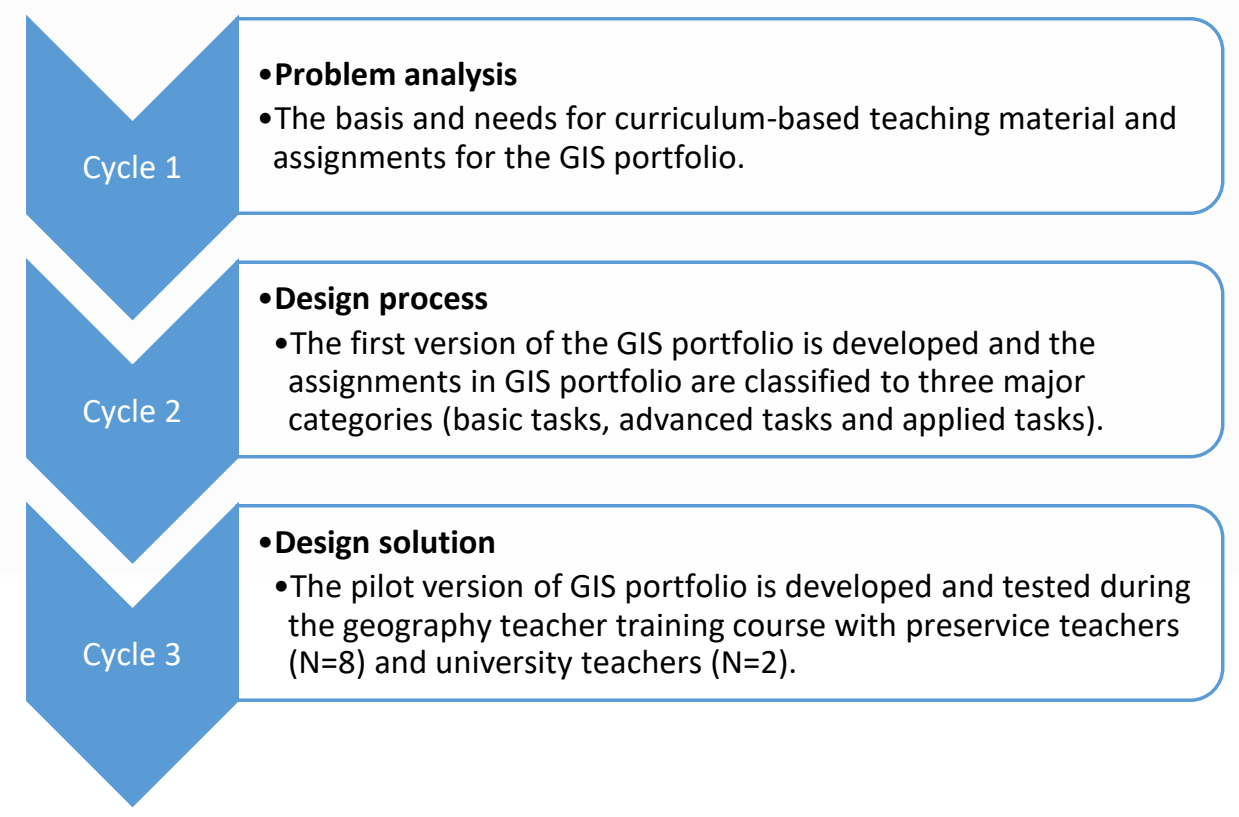


Phase 2

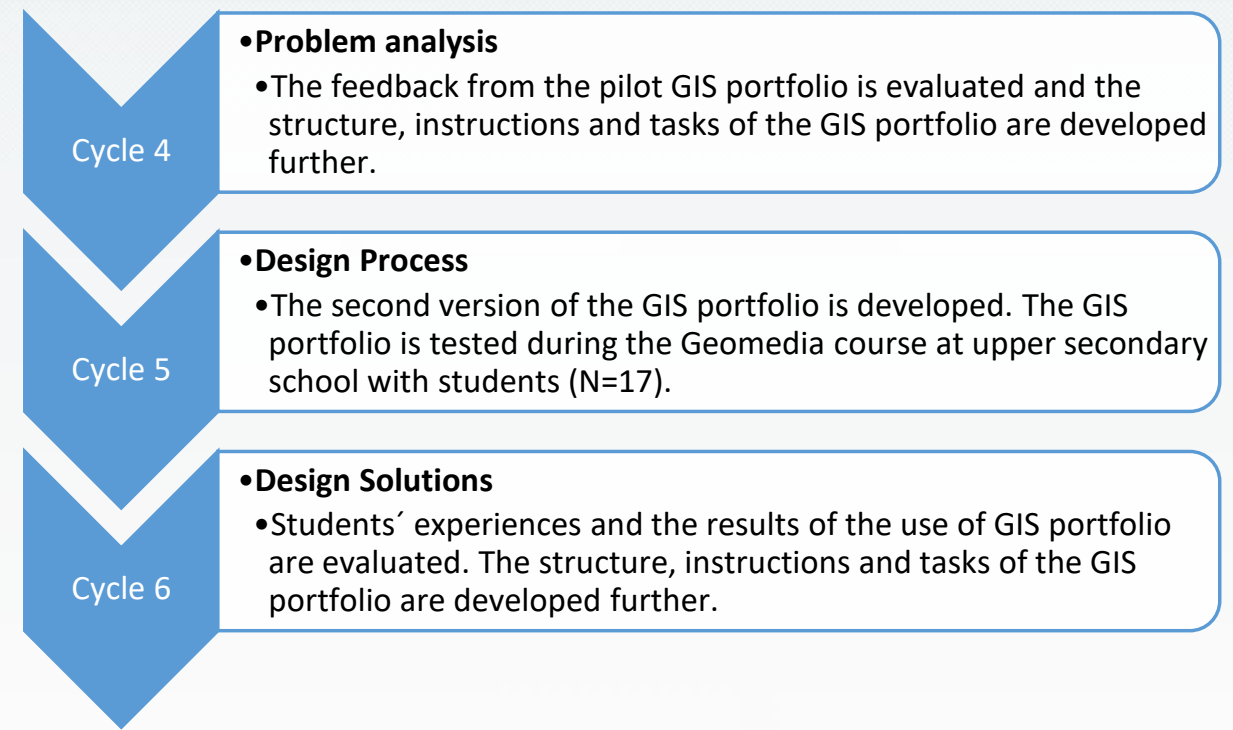

Figure 1. The model presents the entire progression of design-based research

The empirical study was conducted in two phases. Each phase includes three design cycles: 1) problem analysis, 2) design process and 3) design solution (Figure 1). By implementing the study according to the DBR cycles, it is possible to construct design solutions that meet the design challenges and objectives (Pernaa, 2012). Phase 1 of the research was a pilot design, and this research occurred during January 2019 with pre-service Geography teachers at a university in Finland. Phase 2 was the actual design research, and this occurred between February and May 2019 at an upper secondary school in a local municipality. The sample group represents a regular, high school group of students in a Finnish public school.

The first phase (cycles 1-3) of the DBR process explored the factors promoting curriculum-based GIS instruction and the needs of pre-service teachers for GIS instructional materials. The foci of the first phase were to gain an understanding about the nature of appropriate GIS activities, obtain feedback about the challenges, and obtain feedback about the potential to use developed instructional materials. Following Bloom's taxonomy (Anderson \& Krathwohl, 2001), the assignments of the digital GIS portfolio were hierarchically organized.

In the third cycle of the DBR for Phase 1, the pre-service teachers and university teachers tested the tasks of the digital GIS portfolio. After the pilot experiment, the participants provided feedback, comments and ideas for further development about the assignments and instructional materials.

In the second phase of this study (cycles 4-6), the instructional material was tested in practice. The most important thing was to gain insights about how the use of a digital GIS portfolio in an authentic teaching setting will influence student levels of competence in GIS use, including student experiences, levels and indicators of motivation and learning outcomes. 


\section{Context of the Research and Participants}

This first phase of this research was conducted at a university in Finland with pre-service Geography teachers who were completing an optional course focused on technology-supported teaching in Geography. Participants were Geography educators at the university $(n=2)$ and pre-service teachers $(n=8)$ who specialized in teaching Geography and Biology. All participants held at least a minor in Geography and had also completed courses in pedagogical studies as well as practical teacher training periods. The second phase was carried out at a local upper secondary school in Finland. The participating high school students $(n=17)$ were aged between 16 and 17 years. The students completed three courses in Geography at the upper secondary level before taking part in the Geomedia course. The course was designed as a GIS practice example following the aims and content of the national, specialization Geography course (GE4 Geomedia). The course included introductory lessons ( 4 x 75 minutes) given by an experienced Geography teacher who possessed basic GIS skills. After the instructions and assessment criteria were explained to the students, they started their practical work with GIS. Students were advised to produce a digital GIS portfolio using the ArcGIS Online Web Map Application (StoryMap) to document the practical development of their GIS skills and knowledge. StoryMap allows the building of a GIS portfolio which includes digital maps and other geomedia resources. Furthermore, StoryMap provides the abilities to view the portfolio online or print it in PDF format (Esri, 2018).

With some technical support from their teacher about the use of StoryMap, students could independently examine and explore assignments related to their living environment using different geomedia resources whilst specifically focusing on the use of GIS. Activities of the GIS portfolio were related to diverse issues of physical and human geography in accordance with the main aim of Geography education: to integrate themes of the natural and social sciences. The students completed different tasks about their local community to gain a deeper understanding of space in this learning situation (Barnikel \& Ploetz, 2015).

In practice, students were asked to select two or three assignments from the themes of physical geography, and two or three assignments from the themes of human geography. The chosen assignments had to be appropriate for their level of competence and learning objectives. A total of six tasks were to be included in the portfolio. Examples of the digital GIS portfolio assignments include:

Basic task: Find the location of the study area and mark it on the map.

Advanced task: Make a map describing the population density of the study area using Esri Online map layers.

Applied task: Investigate the flood risk in the area by analyzing the town plan and the "Flood Risk" using open GI data produced by the local authorities.

Applied task: Plan and carry out a small-scale study in the area, where you use available open GI data (e.g. Esri, National Land Survey of Finland, Finnish 
Environment Institution) or collect the data yourself with a mobile application (e.g. ArcGIS Collector).

The last part of the course included completing GIS-based assignments from the Matriculation Examinations (ME) of previous years. The tasks were carried out under teacher guidance, and each student completed the assignments independently by following the teacher's instruction.

\section{Data Collection and Analysis}

The data consist of interviews from one teacher educator and two pre-service teachers ( $n=3$, mean duration: 71 minutes); a combination of learning diaries from pre-service teachers and high school students ( $n=25$, mean: 2.6 pages); and semistructured questionnaires from all the participants $(n=27)$. The semi-structured interviews focused on pre-defined research questions using a semi-structured protocol. The data from the semi-structured interview were transcribed into text.

The design-based-research (DBR) process was accompanied by intense evaluation, testing and feedback gathering, so a mixed method approach was applied. Qualitative and quantitative data collection enables the acquisition of both an overview about the general nature of responses as well as gaining deeper insights into the topic. In the first phase of the research, the key research instruments were the learning diaries and questionnaire from the pre-service teachers. The respondents assessed the usability and appropriateness of the digital GIS portfolio as a teaching method by using a five-point Likert scale (1=Strongly Disagree, 2=Disagree, 3=Neutral, 4=Agree, 5=Strongly Agree). Responses to the open-ended questions and the follow-up semi-structured interviews deepened and complemented the respondents' assessments. As respondents were already welleducated pre-service teachers and teacher educators, it was possible to collect several useful comments about areas for potential improvement. Based on the comments and feedback received, changes were made to the instructional materials.

Data were analyzed mainly with a qualitative theory driven content analysis approach (Tuomi \& Sarajärvi, 2002) which applied a grounded theory coding process (Flick, 2018; Table 1). Quantitative methods were also used to analyse questionnaires responses so as to support the qualitative interpretation of data. The use of a mixed-method approach improves the reliability of the research, and was justified to achieve a more in-depth understanding about the data collected in response to the research questions (Metsämuuronen, 2006; Flick, 2018).

Content analysis proceeded through three phases according the process of grounded theory. Accordingly, preliminary assumptions, theories or hypotheses were not applied in advance to the subject being studied, but the core categories of the theoretical framework were formulated in working with the empirical data. In other words, the grounded theory approach prioritizes the data under study over theoretical assumptions (Flick, 2018). 
In the first phase of the analysis, the starting point was the initial coding. For the initial coding, the units of analysis relevant to the research questions were separated from 1 ) the pre-service teachers' learning diaries $(n=8) ; 2)$ the open-ended answers to the questionnaires $(n=8)$; and 3$)$ the interview data $(n=3)$. In this study, the unit of analysis means one or more sentences that deal with the respondent's view about factors which contribute to GIS education, the features of appropriate GIS instructional materials, and challenging or difficult issues faced in teaching about the use of GIS.

Table 1

An Example of Grounded Theory Coding

\begin{tabular}{|c|c|c|c|c|c|}
\hline Example data & $\begin{array}{l}\text { Coding } \\
\text { rule }\end{array}$ & $\begin{array}{c}\text { Sub- } \\
\text { category }\end{array}$ & $\begin{array}{c}\text { Core } \\
\text { category }\end{array}$ & $\begin{array}{l}\text { Frequencie } \\
s \text { of the } \\
\text { unit of } \\
\text { Analysis (f) }\end{array}$ & 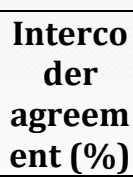 \\
\hline $\begin{array}{l}\text { As a teacher, one } \\
\text { should manage } \\
\text { different GIS } \\
\text { programs well and } \\
\text { be able to help } \\
\text { students. }\end{array}$ & $\begin{array}{l}\text { What } \\
\text { factors } \\
\text { contribute } \\
\text { to the } \\
\text { teaching of } \\
\text { GIS? }\end{array}$ & $\begin{array}{l}\text { Teacher training } \\
\text { Teacher's } \\
\text { experience } \\
\text { Adequate ICT } \\
\text { skills of teacher }\end{array}$ & $\begin{array}{l}\text { Teacher's } \\
\text { competence }\end{array}$ & 23 & $92 \%$ \\
\hline $\begin{array}{l}\text { Appropriate and } \\
\text { functional } \\
\text { applications for } \\
\text { producing GIS } \\
\text { data and projects. } \\
\text { Free software and } \\
\text { data. }\end{array}$ & $\begin{array}{l}\text { What } \\
\text { factors } \\
\text { contribute } \\
\text { to the } \\
\text { teaching of } \\
\text { GIS? }\end{array}$ & $\begin{array}{l}\text { Availability of } \\
\text { GIS software and } \\
\text { data } \\
\text { Easy-to-use GIS } \\
\text { software and } \\
\text { data }\end{array}$ & $\begin{array}{l}\text { User-friendly } \\
\text { GIS software } \\
\text { and data }\end{array}$ & 50 & $78 \%$ \\
\hline $\begin{array}{l}\text { Therefore, it is } \\
\text { true that if there } \\
\text { were a ready- } \\
\text { made idea or an } \\
\text { entity that would } \\
\text { be done, then it } \\
\text { would be so easy } \\
\text { for other teachers } \\
\text { to start } \\
\text { implementing it. }\end{array}$ & $\begin{array}{l}\text { What } \\
\text { factors } \\
\text { contribute } \\
\text { to the } \\
\text { teaching of } \\
\text { GIS? }\end{array}$ & $\begin{array}{l}\text { Ready-made task } \\
\text { templates } \\
\text { Clear } \\
\text { instructions and } \\
\text { tutorials } \\
\text { Availability of } \\
\text { tasks and } \\
\text { tutorials }\end{array}$ & $\begin{array}{l}\text { Complete GIS } \\
\text { tutorials and } \\
\text { different } \\
\text { types of GIS } \\
\text { assignments }\end{array}$ & 19 & $79 \%$ \\
\hline $\begin{array}{l}\text { It has to do with } \\
\text { the digital stuff. }\end{array}$ & $\begin{array}{l}\text { What } \\
\text { factors are } \\
\text { challenging } \\
\text { in teaching } \\
\text { of GIS? }\end{array}$ & $\begin{array}{l}\text { Insufficient ICT } \\
\text { skills of teacher } \\
\text { Little experience } \\
\text { of teacher } \\
\text { Teacher's } \\
\text { attitude } \\
\text { Shortage of time }\end{array}$ & $\begin{array}{l}\text { Insufficient } \\
\text { competence } \\
\text { of teacher } \\
\text { Insufficient } \\
\text { time resource }\end{array}$ & 11 & $91 \%$ \\
\hline
\end{tabular}

In the second phase of the data analysis process, and in accordance with qualitative content analysis and grounded theory (Tuomi \& Sarajärvi, 2002; Flick, 2018), the coding rules were based on the units of analysis from the data. According to coding rules, the units were classified into sub-categories. The sub-categories provided structure and defined the core categories (Table 1). Based on the grouping of sub-categories, the following core categories were formed: 1) teacher 
competency in GIS; 2) user-friendly GIS software and data; and 3) complete GIS tutorials and different types of GIS assignments. In the analysis of data, the following were listed: the frequencies of units of analysis (f); plus, the sub-categories, core categories, coding rules and data examples to illustrate the coding rules of different categories (Table 1).

The first author of this article classified all the data, and the second author classified $67 \%$ of the data to assess the reliability of the classification categories. The percentages of congruent coding were documented, and if the percentage of coding was more than $70 \%$, the reliability was considered good (Table 1).

In the third cycle of the study for Phase 1, the data from the semi-structured interviews conducted with pre-service teachers and teacher educators $(n=10)$ were analyzed by a quantitative approach. The quantitive approach examined descriptive indicators such as frequencies and averages. Descriptive statistics will describe or summarize the distribution of the variables (Neuendorf, 2016) which, in this study, were the respondents' assessments about the use of a digital GIS portfolio in the Geomedia course.

In the second phase of the study, the high school students filled-in a semistructured self-evaluation about their GIS competence. The self-evaluations were completed before and after the course, and students made notes in their learning diaries during the course. The assessment of progress in the development of students' GIS skills from the beginning to the end of the course (summative evaluation) occurred through an initial and subsequent self-evaluation form. Students completed the self-assessment using the Likert scale scored as follows: $1=$ No skills, $2=$ =Poor skills, $3=$ Basic skills, $4=$ =Advanced skills, $5=$ Excellent skills. The data from the semi-structured interviews conducted with the students $(n=17)$ were analyzed using statistical methods, such as descriptive indicators of the results. Furthermore, the learning diaries of the students $(n=17)$ were studied using content analysis.

All the semi-structured interviews were anonymous. Therefore, pre-service teachers and students were able to give their feedback without concerns that their comments would influence their grading and grades.

\section{Findings}

\section{Which Factors Affect the Teaching of GIS Competencies?}

The analysis of learning diaries and semi-structured interview responses from pre-service teachers revealed the most important factors to contribute to the teaching of GIS are: 1) user-friendly GIS software ( $\mathrm{f}=50)$; 2) teacher's GIS competence ( $\mathrm{f}=23)$; and 3 ) complete GIS tutorials and different types of GIS assignments $(\mathrm{f}=19)$.

Most pre-service teachers reported the ease of use for GIS software contributes to the teaching of GIS. Here is a typical example of a respondent's comment: 
"If the available GIS applications are difficult to use, teaching is also difficult."

Furthermore, respondents agreed the teacher's own ICT skills in promoting GIS education is of primary importance. For instance:

"If the teacher has good ICT skills, the use of GIS programs will also be smooth."

In general, responses revealed that ready-made assignments with instructions and easy-to-implement entities were needed for practical GIS teaching.

"There should be good, clear and concise instructions for using high-quality

digital (GIS) resources to make it easy to get started with the software."

According to the responses about factors affecting the teaching of GIS and the prerequisites for instructional materials in GIS education, the first version of a digital GIS portfolio was developed and tested with university teachers and pre-service teachers.

The pilot phase (Phase 1) revealed the potential of a digital GIS portfolio to developing competence in teaching GIS. The statements from respondents showed that the structure, which followed Bloom's taxonomy, was found to be suitable for the Geomedia course (4.2/5), and the tasks in the digital GIS portfolio were useful (4.4/5), interesting (4.2/5), challenging (4.4/5) and appropriate for achieving the objectives of GIS education (4.6/5). The following quotations from open questions and learning diaries illustrate how pre-service teachers and a university teacher described their experiences of the pilot phase:

"Teaching is too often focused on how different GIS applications are used and not on what issues can be explored using the software."

"We (preservice teachers) learned how to use GIS through the tasks planned for the Geography course in high school, and these tasks provided a good starting point for me to be a Geography teacher in the future and to create appropriate tasks for students."

"I learned that, with students it's worth proceeding from the easiest thing to the hardest. This is how everyone gets to experience success."

Overall, the respondents provided positive feedback about the use of a digital GIS portfolio to support the teaching of GIS skills. However, results revealed that there are also difficulties. The reason mentioned most often as being the biggest challenge to teaching GIS skills ( $\mathrm{f}=11$ ) was lack of teacher competence in the use of GIS competence. Another challenge mentioned was limited time $(\mathrm{f}=5)$. The following excerpts from the responses explain such difficulties in the use of GIS:

"The most challenging and time-consuming thing is learning different programs and how to use them."

"If the teacher does not have GIS skills, then how would the students learn?" 
"That if it (utilizing GIS) is not taught in school, will (the student) actually get those skills from anywhere else...? So that (the student) could use even those simple programs."

\section{How Does the Use of Digital GIS Portfolios Contribute to The Development of GIS Competencies in Students?}

In the second phase of the study, according to the problem analysis of the fourth cycle of DBR, the tasks and instructions were further developed. In the fifth cycle, the digital GIS portfolio was tested in an authentic learning context with high school students $(n=17)$ who were completing the Geomedia course.

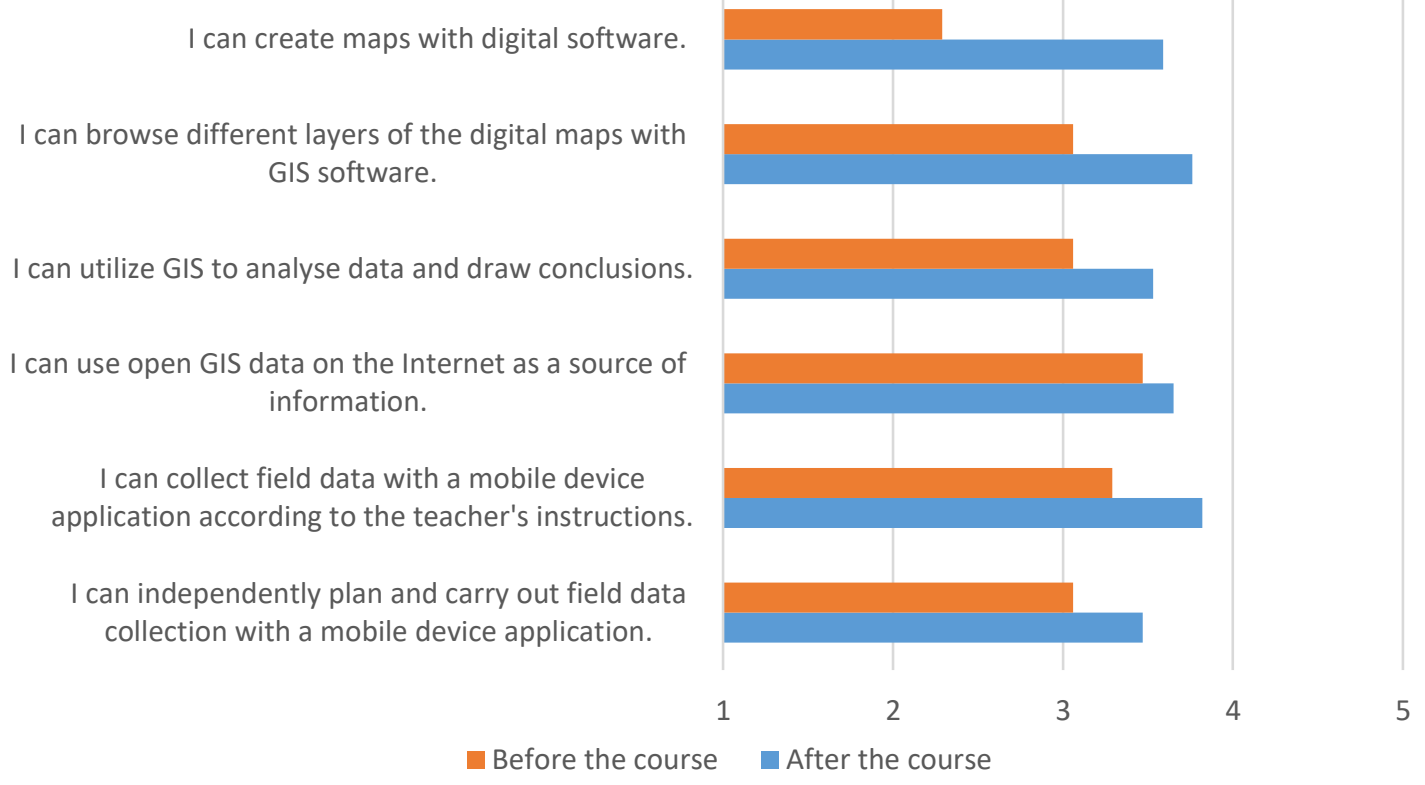

Figure 2. Students $(n=17)$ perceived GIS skills before and after the Geomedia course according to the self-evaluation (Scale 1= No skills...5= Excellent skills).

Students perceived their competence in GIS improved for all assessed skills (Figure 2). Before the course, students evaluated themselves as having poor skills $(2.29 / 5)$ at making digital maps. After the course, students estimated themselves to have basic skills (3.59/5). Additionally, students made progress in utilizing geographic information systems and data. Before the course, the average student evaluated their skills at browsing different layers of GIS data or utilizing GIS to draw conclusions as basic (3.06/5) yet after the course both skills-sets were slightly improved. There was little progress in student ability to utilize open GIS data. Before the course the score was 3.47/5, and after the course the score was 3.65. According to student responses, the teacher-guided and independently conducted mobile GIS data collection skills developed their competence in the use of GIS.

At the beginning of the course, responses to the initial semi-structured interview revealed students considered their level of GIS competence to be quite important. After completing the Geomedia course, expertise in the use of GIS was considered to 
be even more important (Figure 3). Improved student attitudes became clear also from their open answers and learning diaries as they mentioned successful and unsuccessful experiences. Examples of students' quotes are seen in the following:

"I take advantage of the GIS applications almost daily. Doing GIS tasks is fun, and it is useful for different professions."

"Basic GIS skills are very often needed, but the advanced skills hardly ever, especially in everyday life. GIS is useful, but I can't do it myself."

"GIS is versatile and can be utilized in different subjects."

I have very poor GIS skills.
I don't consider learning GIS important at all.
There is no use for GIS in everyday life.
There is no use for GIS in work life.
Utilizing GIS is very difficult.
I am not at all motivated to learn GIS.
GIS education is very necessary in high school.
Ino use for GIS in science and research.

Figure 3. Students' ( $n=17$ ) perception concerning the use of GIS and the importance of GIS competence before and after the Geomedia course.

Student responses revealed that performing the most demanding tasks in the GIS portfolio may have weakened their perception about their own GIS skills compared to the initial situation. However, students were able to enhance their understanding about the possibilities of GIS in different sectors of society such as science and worklife as well as in everyday life. Minor positive changes were observed in students' motivation to learn about the use of GIS skills (Figure 3). Although students felt that GIS skills were important, a deeper understanding about the use of GIS was considered difficult, and so it has a demotivating effect. 


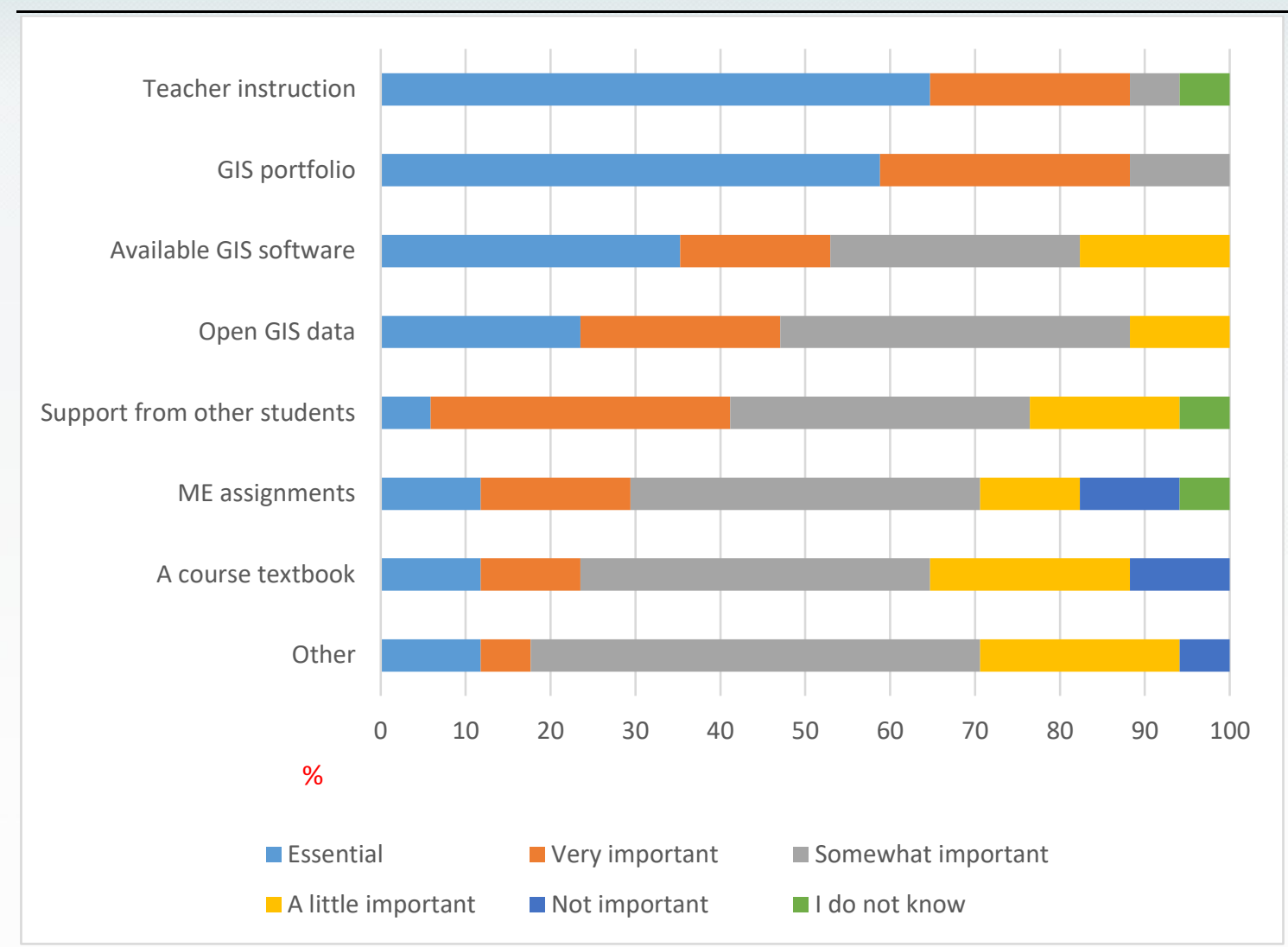

Figure 4. Distribution of answers ( $n=17)$ to the question "Which factors contributed to your GIS learning during the course?"

According to student responses, the instruction from the teacher and independent completion of the GIS-related tasks in the portfolio were the most important factors to support the development competence in the use of GIS (Figure 4). On the other hand, responses suggested the course textbook with its assignments or matriculation exam tasks from previous years did not significantly contribute to the improvement of GIS skills. Students found that other factors (such as tutorial GIS videos and studying online independently) provide support for learning their GIS skills. The analysis of students' learning diaries and answers to open questions produced the following comments

"It (GIS portfolio) was a new and nice method of study."

"The GIS portfolio was easy and nice to do, but it may have included too much to work for one course."

"Finding the time to do your portfolio was difficult, but it was somehow possible. I couldn't do some of the tasks in the portfolio, but I realized their benefits while completing the portfolio."

"I like the way that the teacher shows me how to do the task, and I follow her on my own computer."

"The GIS portfolio and teacher's advice are useful ways to teach GIS in high school." 
"Teacher-led learning is the best way."

Implementing the course using a digital GIS portfolio met the objectives for the course well (Figure 5). Self-evaluation reports from the students revealed that their skills to acquire, process, analyze, interpret, evaluate and present geographic data improved during the course. Results also showed that geographical thinking increased as students developed their ability to pose geographical questions and use geomedia to solving geographical problems. Furthermore, students learned to use geographical information system applications better than before the course. According to responses, most students also improved their skills in using geomedia when preparing a geographic study or were completing a participation and/or involvement project (Figure 5).

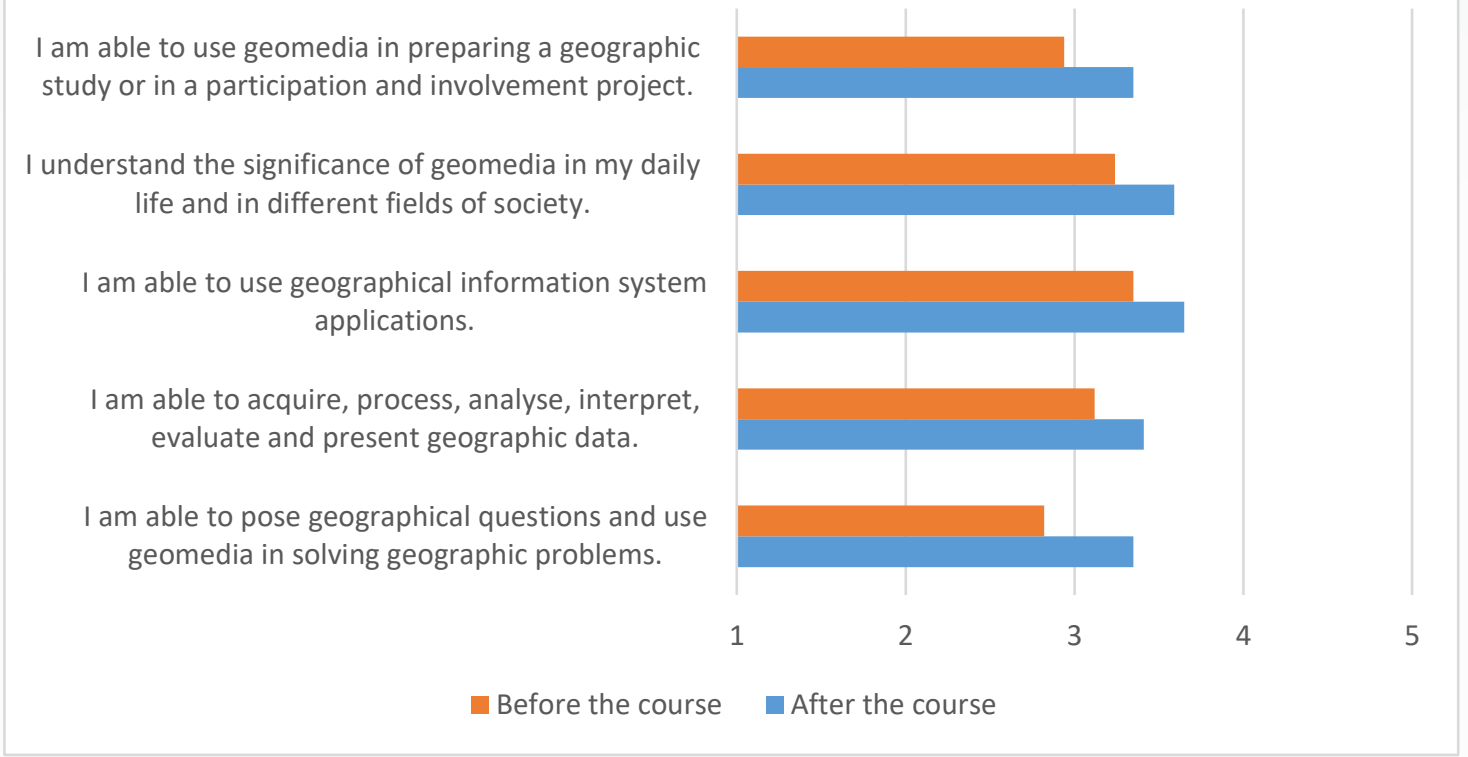

Figure 5. Students' ( $n=17)$ self-evaluation of their own competence in terms of course objectives before and after the course (Scale 1=strongly disagree...5=strongly agree).

\section{Discussion}

It is obvious to promote advancement in GIS education demands a new approach in teacher training at universities. By using the design-based-research (DBR) approach, the study provides an example of a practical case study about how to engage pre-service teacher in developing instructional material for GIS education. The main results indicate that pre-service teachers need training to develop their ability to teach GIS skills. Pre-service teachers also need easy-to-use GIS software and readily-available instructional material. Results from this study confirm findings from the work of Barnikel \& Ploetz (2015): that without easy accessibility of online material, teachers cannot be expected to significantly contribute towards the development of GIS competence in their teaching. 
Another research priority of the current study was to examine the value of an educational portfolio in the context of secondary level GIS education. The empirical research project was initiated to ascertain how the implementation of a digital GIS portfolio in teaching and learning will affect the development of competence in the use of GIS amongst students. This study explored what worked and what did not work within using such a pedagogical approach. Empirical information collected from the DBR process showed that carefully designed and properly implemented instructional materials improved students' perception about their learning related to the use of GIS.

Using an educational portfolio in GIS education demands the design of instructional materials that build upon students' prior geographic knowledge, skills and experience. This study emphasizes the importance of versatile tasks in a GIS portfolio; the tasks need to proceed from easy to difficult because it allows students to progress at their own pace. Such an approach responds to Barnikel \& Ploez's (2015) notion that students are heterogeneous in their skills yet require differentiation in instruction at different levels. The ownership of learning must shift from the teacher to being the responsibility of the learner in the planning process for implementing learning activities.

The research findings strongly indicate that a teacher is needed to guide the student-centered learning process. For pre-service and in-service teachers, this is a clear message - to teach GIS skills effectively to students, the teacher needs to be competent and know those skills well. Such a finding sets requirements for teacher training in Geography, where pre-service Geography teachers should be supported to acquire sufficient GIS competencies so they are equipped to teach the 21st Century skills related to the field of Geography.

Results from the current study confirms the results of previous studies. Students have a positive attitude towards the use of GIS in Geography teaching. Students enjoy participating in classrooms where GIS is used as these classes become more interesting and active (West, 2003; Esteves \& Rocha, 2015). The new gateways to knowledge (such as open GIS data and digital maps) and wide access to GIS software provide facilities to design versatile GIS tasks that are not textbook based. Mobile technology enhanced learning provides great facilities to support the individual formation of knowledge based on data collection (Chatel \& Falk, 2017; Lee, 2020). With regard to this potential, the digital GIS portfolio could have included more diversity in assignments utilizing mobile devices and mobile data collection activities.

\section{Conclusion}

In this study, a model digital portfolio for GIS education was developed collaboratively with pre-service teachers and university teachers, and the applicability of the portfolio was tested in a practical learning situation at upper secondary school level. Such collaboration is mutually beneficial since pre-service teachers have the opportunity to participate in designing and testing a challenging 
subject area such as GIS (Kerski, 2003; Favier \& Schee, 2014). In addition, collaboration between people within and outside of academia narrows the gap between research and practice (see also Vuopala et al., 2020).

Geographic competence assessment has been criticized for the fact that teachers often use only traditional assessment methods (Sözen, 2019). GIS applications and software offer useful tools for the documentation of learning (Chatel \& Falk, 2017). The use of student portfolios in evaluation offers additional value for continuous assessment practices (formative assessment), as students are able to show their skills and performance in Geography by collecting their best outputs in a portfolio. This study did not specifically focus on the use of a portfolio to support assessment, but it would be an issue worthy of further study.

This design-based-research (DBR) approach contributes to a need to develop new methods for teacher training. The advantage of the DBR process is that it helps pre-service teachers to develop geographic perspectives and skills, and associate knowledge of the Geography curriculum and practice. In the future, pre-service teachers may independently be able to implement the tasks developed for a digital GIS portfolio in the context of an authentic learning situation with high school students. The current research findings support the need identified from previous studies about it being important to ensure that future teachers will have exposure to GIS during their scientific and pedagogical training (Esteves \& Rocha, 2015). DBR is a promising approach but a lot remains to be done in terms of teacher training and finding the best practices to work with GIS software in classrooms.

A combination of student enhanced perceptions about the relevance of GIS and their development of GIS competencies during the Geomedia course suggests that use of a digital GIS portfolio is a promising pedagogical method in GIS education. However, there has been little scientific research focusing on the use of a portfolio in teaching GIS skills, making it difficult to confirm the results of this case study by comparing it with previous studies. In addition, due to the small number of participants, these results are not statistically representative, but they do provide a starting platform for the discussion. The pedagogical method offered by the digital GIS portfolio also needs to be evaluated in terms of some criticisms, in particular concerning the evaluation of standardized learning results. Whilst recognizing these concerns, it can be suggested that the use of a digital GIS portfolio is well suited for the teaching and learning of GIS although further quantitative research is recommended to further clarify this relationship. 


\section{References}

Anderson, L. W. \& Krathwohl, D. R. (2001). A Taxonomy for learning, teaching, and assessing: A revision of Bloom's taxonomy of educational objectives (Abridged edition.). New York: Longman.

Anunti, H., Vuopala, E. \& Rusanen, J. (2018). Lukiolaisten kokemuksia geomedian käytöstä tutkivassa oppimisessa. High school students' experiences of using geomedia in problem-based learning. Terra, 130 (1), 17-30.

Baker, T., Kerski, J., Huynh, N., Viehrig, K. \& Bednarz, S. (2012). Call for an agenda and center for GIS education research. Review of International Geographical Education Online (RIGEO), 2(3), 254-288.

Baker, T., Battersby, S., Bednarz, S., Bodzin, A., Kolvoord, B., Moore, S., Sinton, D. \& Uttal, D. (2015) A research agenda for geospatial technologies and learning, Journal of Geography, 114(3), 118-130.

Barnikel, F. \& Ploetz, R. (2015). The acquisition of spatial competence - fast and easy multidisciplinary learning with an online GIS. European Journal of Geography, 6(2), 614.

Bearman, N., Jones, N., André, I., Cachinho, A. H. \& DeMers, M. (2016). The future role of GIS education in creating critical spatial thinkers. Journal of Geography in Higher Education, 40 (3), 394-408.

Chatel, A. \& Falk, G. (2017). Smartgeo - mobile learning in geography education. European Journal of Geography, 8(2), 153-165.

Donert, K., Desmidt, F., de Lázaro Y Torres, M. L., González, R. D. M., Lindner-Fally, M., Parkinson, A. \& Zwartjes, L. (2016). The GI learner approach: Learning lines for geospatial thinking in secondary schools. GI_Forum, 2, pp. 134-146.

Edelson, D. (2002). Design research: What we learn when we engage in design. The Journal of the Learning Sciences, 11 (1), 105-121.

Esri (2018). Building a GIS portfolio. Retrieved from:https://downloads.esri.com/ learnarcgis/educators/building-a-gis-portfolio.pdf.

Esteves, M. H. \& Rocha, J. (2015). Geographical information systems in Portuguese geography education. European Journal of Geography, 6(3), 6-15.

Favier, T. \& Schee, J. (2014). Digital Earth and geography teacher training for the $21^{\text {st }}$ century: teacher competences for inquiry-based geography teaching. In: Donert, K. \& Miguel Gonzalez, R. de. (2014). Innovative learning geography in Europe: new challenges for the 21st century. Cambridge Scholars Publishing.

Flick, U. (2018). Qualitative research kit: doing grounded theory. 55 City Road, London: SAGE Publications Ltd. GI Learner Competences (version 2017). Retrieved from: http://www.gilearner.ugent.be/wp-content/uploads/GI-Learner-competencies.pdf

Havelková, L. \& Hanus, M. (2019). Map skills in education: a systematic review of terminology, methodology, and influencing factors. Review of International Geographical Education Online (RIGEO), 9(2), 361-401. 
Hirvensalo, V. \& Koskelo, K. (2014). Paikkatietotekniikalla innovatiivisuuta maantieteen kouluopetukseen. Terra, 126(4), 187-196.

Kerski, J.J, Demirci, A. \& Milson, A. (2013). The global landscape of GIS in secondary education. Journal of Geography, 112(6), 232-24.

Kerski, J. J. (2003). The implementation and effectiveness of geographic information systems technology and methods in secondary education. Journal of Geography, 102(3), 128-137.

Lee, J. (2020). Designing an inquiry-based fieldwork project for students using mobile technology and its effects on students' experience. Review of International Geographical Education Online (RIGEO), 10(1), 14-39.

Lukion opetussuunnitelman perusteet (2019). Helsinki, Opetushallitus, Finnish National Board of Education, 2019.

Martin-Kniep, G. (1998). Why am I doing this? Purposeful teaching through portfolio assessment. Heinemann, 196.

Metsämuuronen, J. (2006). Tutkimuksen tekemisen perusteet ihmistieteissä: Tutkijalaitos. 3. Edition. International Methelp, Helsinki.

National Core Curriculum for General Upper Secondary Schools (2015). National core curriculum for general upper secondary education intended for young people. Helsinki: Finnish National Board of Education, 2016.

Neuendorf, K. (2016). The Content Analysis Guidebook (Second Edition). SAGE Publications, Inc.

Oikarinen, J. (2016). Technology-enhanced statistics learning experiment. A case study at upper secondary level. University of Oulu. Universitatis Ouluensis E168.

Pernaa, J. \& Aksela, M. K. (2012). Model-based design research: A practical method for educational innovation in Antoncic, B. (ed.), Advances in Business-Related Scientific Research Conference 2012 in Venice: Conference proceedings. Venice, BusinessRelated Scientific Research Conference - ABSRC 2012, Venice, Italy, 28/03/2012.

Schell, E., Roth, K., Mohan, A., Edelson, D., Shavelson, R., Wertheim, J., Bednarz, S.,Heffron, S. \& Huynh, N. (2013). A road map for $21^{\text {st }}$ century geography education.

Executive summary for the Road Map for 21 ${ }^{\text {st }}$ Century Geography Education Project. National Geographic Society.

Schubert, J. C. \& Uphues, R. (2009). "Learning with geoinformation in German schools: systematic integration with a GIS competency model." International Research in Geographical and Environmental Education, 18(4), 275-286.

Simon, M. \& Forgette-Giroux, R. (2000). Impact of a content selection framework on portfolio assessment at the classroom level. Assessment in Education: Principles, Policy \& Practice, 7(1), 83-100.

Sözen, E. (2019). High school students' views and attitudes towards geography courses in Turkey. Review of International Geographical Education Online (RIGEO), 9(2), 458478. 
Tate, N. J. \& Jarvis, C. H. (2017). Changing the face of GIS education with communities of practice, Journal of Geography in Higher Education, 41(3), 327-340.

Tuomi, J. \& A. Sarajärvi. (2002). Laadullinen tutkimus ja sisällönanalyysi. p. 159. Kustannusosakeyhtiö Tammi, Helsinki.

Tuomisto, M. (2018). Design-based research: Educational chemistry card and board games. Academic Dissertation. The University of Helsinki. 175.

Ugodulunwa, C. \& Wakjissa, S. (2015). Teaching map sketching and location in secondary school geography in Jos, Nigeria. Journal of Education and Practice, 6(17), 23-31.

Vartiainen, J. (2016). Kehittämistutkimus: Pienten lasten tutkimuksellisen luonnontieteiden opiskelun edistäminen tiedekerho-oppimisympäristössä. Academic Dissertation. The University of Helsinki.

Vuopala, E. \& al. (2020). Implementing a maker culture in elementary school - students' perspectives technology. Pedagogy, and Education. Accepted for publication.

West, B. A. (2003). Student attitudes and the impact of GIS on thinking skills and motivation, Journal of Geography, 102(6), 267-274.

Zwartjes, L. \& de Lázaro y Torres, M. L. (2019) Geospatial Thinking Learning Lines in Secondary Education: The GI Learner Project. In: de Miguel González R., Donert K. \& Koutsopoulos K. (eds) Geospatial Technologies in Geography Education. Key Challenges in Geography. EUROGEO Book Series. Springer, Cham.

\section{Biographical Statements}

Henna ANUNTI MSc, is a geography, biology and health education teacher and vice principal at Ii Upper Secondary School, Finland. As a PhD student at the Geography Research Unit, University of Oulu, she is very interested in designing innovative teaching and learning methods in science, especially in the field of GIS education.

Essi VUOPALA PhD, is a university lecturer in the Learning and Educational Technology Research Unit (LET) in the Faculty of Education, University of Oulu, Finland. Her research interests deal with collaborative learning, including inquiry learning, and technologyenhanced learning, especially from the viewpoint of social interaction and knowledge coconstruction in the higher education context. She is currently a lecturer in the International Learning, Education, and Technology Master's Degree Program.

Jarmo RUSANEN PhD, is an emeritus professor of geoinformatics at the Geography Research Unit, University of Oulu, Finland. Currently he is involved with research projects on health geography and GIS education. He supervises doctoral students at the University of Oulu Graduate School (UniOGS). 